\title{
Assessing Health Damages from Improper Disposal of Solid Waste in Metropolitan Islamabad-Rawalpindi, Pakistan
}

\author{
Tanzila Akmal * and Faisal Jamil
}

Citation: Akmal, T.; Jamil, F. Assessing Health Damages from Improper Disposal of Solid Waste in Metropolitan Islamabad-Rawalpindi, Pakistan. Sustainability 2021, 13, 2717 https://doi.org/10.3390/su13052717

Academic Editor: Antoni Sánchez

Received: 6 January 2021

Accepted: 22 February 2021

Published: 3 March 2021

Publisher's Note: MDPI stays neutral with regard to jurisdictional claims in published maps and institutional affiliations.

Copyright: (c) 2021 by the authors. Licensee MDPI, Basel, Switzerland. This article is an open access article distributed under the terms and conditions of the Creative Commons Attribution (CC BY) license (https:// creativecommons.org/licenses/by/ $4.0 /)$.
School of Social Sciences and Humanities, National University of Sciences and Technology (NUST), Islamabad 44000, Pakistan; faisal.jamil@s3h.nust.edu.pk

* Correspondence: tanzilaakmal@s3h.nust.edu.pk or tanzilaakmal143@gmail.com

\begin{abstract}
Rapid urbanization in developing countries leads to a dramatic increase in solid waste production, with serious socio-economic and ecological impacts. In order to avoid the associated hazards, particularly those related to human health and the environment, solid waste management is indispensable. Disposal of municipal waste that predominantly comprises household and commercial refuse has become a daunting task for local governments and municipalities of Pakistan. Issues related to both inadequacy of service delivery and inappropriate disposal signify that waste management should be high on the local environment policy agenda. In particular, the external cost of waste management is high, and cost recovery of refuse collection may cause the exclusion of many households and additional costs on the households that avail themselves of the service. In this study, we carried out an evaluation of the health damage caused by improper waste disposal in a sample of heterogeneous households. The study shows a framework for evaluating the damages caused by inadequate waste management practices. The results indicate that irregular disposal in the vicinity of residents causes illness: respondents living within $100 \mathrm{~m}$ are more vulnerable to malaria, dengue, and asthma than those living more than $500 \mathrm{~m}$ away. Moreover, the findings highlight that households lack knowledge of waste hazards and $75.9 \%$ of waste is not segregated. We suggest a subsidized waste collection and disposal service provided either by the local government or by outsourcing.
\end{abstract}

Keywords: solid waste management; health hazards; environmental awareness

\section{Introduction}

Rapid urbanization in developing countries leads to a dramatic increase in solid waste production, with serious socio-economic and ecological impacts [1-3]. Poor infrastructure and land use regulations have resulted in inadequate cover of waste collection services and inappropriate disposal. Moreover, poorly managed municipal waste creates many environmental and health-related issues, especially in the neighborhoods of dump sites. Poor urban slum dwellers are particularly vulnerable and are acutely affected by waste dumping [4]. Waste collection is an essential first part of the process of waste management. Ever-growing volumes of solid waste create serious issues in handling and disposing it of aptly in the face of resource constraints in less-developed countries [5]. A weak institutional setup and difficulties in recovering the cost of the service make it difficult for municipal authorities in these countries to collect and segregate the waste from all potential waste producers [6-8].

In most developed countries, a door-to-door collection system is commonly used, but municipalities in developing countries can provide this service to only a limited proportion of the population due to financial and administrative incapacity [9]. As a result, waste is thrown into open landfill sites and dumpsites, which evolve into sources of health and environmental threats for people living in the neighborhood [10]. Because of poorly designed municipal waste management systems, many urban areas in developing countries experience significant environmental deterioration and health threats [11]. Various studies have investigated the health and environmental impacts of waste dumping and have shown 
that waste and health variables are closely linked [12-19]. The conclusion of these studies has led researchers to become deeply involved in the study of environmental pollution and its effects on microorganisms [20]. However, very few studies have explored the environmental and health effects of solid waste for people living near waste dumpsites [21-23].

The increasing rates of the consumption and production of goods result in the generation of a tremendous amount of waste that needs to be absorbed by the environment, posing a serious risk to human health [24]. In many developing countries, waste disposal sites are located in the vicinity of urban areas, and these mini-dumpsites are a source of infection for children due to the incubation and reproduction of mosquitoes, flies, and rodents [25]. They, in turn, produce gastrointestinal, dermatological, respiratory, genetic, and several other types of contagious infections [24,26,27]. Moreover, residents living near dumpsites present increasing rates of stomach and cervical/uterine cancers in women and, likewise, stomach, liver, lung, and prostate cancers in men [28].

Improper disposal of waste also includes that of sharp objects (such as syringes, razors, and blades) that directly pose serious health hazards to waste pickers and disposal workers. Data revealed that more than 250 million people are infected with the Hepatitis B virus, 70 million with Hepatitis $C$, and 38 million with immune deficiency infections worldwide, primarily due to exposure to infected syringes and blades [29,30].

Accordingly, Pakistan is facing serious solid waste management (SWM) problems that have received a lot of attention due to an increase in environmental vulnerability [31]. Recent assessments in major cities of Pakistan showed that the average waste generation rate from all types of municipal controlled areas varies from $0.283 \mathrm{~kg}$ to $0.613 \mathrm{~kg}$ per person each day, and waste production is growing annually at a rate of $3.67 \%$ to $7.42 \%$ [32-34]. In addition, Pakistan ranks highest for poorly handled plastic in South Asia. In Pakistan, 30 million tons of solid waste are produced annually, out of which $9 \%$ are plastics, contributing approximately 0.2 million tons of plastic waste along the Indus river to the Arabian Sea. Almost 55 billion plastic bags are produced in a year and make their way into water streams and landfills, making sewerage systems even harder to manage. Several countries-including Bangladesh, France, and Rwanda - have banned the use of plastic bags. In Pakistan, the Environment Protection Agency (EPA) has also released a Statutory Regulatory Order to ban plastic bags in the Federal Capital, Islamabad, and in other cities, like Lahore and Hunza. Currently, there is no constitutional mandate at the federal and provincial levels that addresses the implications of single-use plastics and plastic waste management in a wider area [35].

Municipal corporations in Pakistan generally provide bins at a community level, which are evacuated after being filled. Waste containers are provided at designated convenient points within a community to enable households to put out their trash. Waste pick-up vehicles are supposed to empty these containers as soon as they are full. However, waste is often overflowing, and land dumping takes place near the bins and on illegal sites [36]. In addition, the paucity of bins increases the time, effort, and cost of waste disposal, and households may, in turn, choose inappropriate dumping on unauthorized sites. Illegal dumping on unauthorized land, in canals and streams, and on roadsides all contaminates canal and ground water supplies [37-39]. Moreover, improperly handled waste blocks sewage, which creates a conducive environment for the breeding of mosquitos that spread malaria, dengue, and other infections [23,40].

The Millennium Development Goals (MDGs) and Sustainable Development Goals (SDGs) have made environmental sustainability and the security of human health a greater focus. As a result of initiatives taken to meet the MDGs, 2.1 billion people now have access to improved sanitation systems in developing countries. The SDG policy encourages waste minimization through extensive waste reuse and recycling activities. For example, SDG-3 is about the well-being and health of people, SDG-6 aims to improve water and sanitation systems, and SDG-11 is directly related to solid waste collection and management. Sewerage is a primary source of water contamination in Pakistan. In certain cases, lax environmental regulations have resulted in the dumping of hazardous and toxic industrial waste in water bodies $[41,42]$. 
In this context, the inadequacy of infrastructure and the inappropriate handling of municipal waste is a matter of great importance. This study aims to outline a comprehensive and feasible policy to address these challenges which would subsequently improve health indicators for urban households. In this study, we carry out an objective assessment of the health damages incurred in twin cities. (Twin cities are a special case of two cities or urban centers which are situated in near geographical proximity, and Islamabad-Rawalpindi are known as twin cities because they are adjacent.) The results derived on the cost of illness will contribute to policy implications for the waste management sector.

The rest of the paper is as follows. Section 2 highlights the waste management practices in the twin cities. Section 3 outlines the literature review used to assess the role of health damages from solid waste. Section 4 outlines the sampling process and survey design and provides an analysis of relevant variables. Section 5 presents and discusses the proposed model. Finally, Section 6 concludes the study.

\section{Household Solid Waste Management Issues in Islamabad-Rawalpindi}

The capital of Pakistan, Islamabad, is the tenth largest city in Pakistan, and the neighboring city of Rawalpindi is the fourth largest. These two cities have populations of 1.019 million and 2.09 million inhabitants, respectively [43]. The terrain is of higher altitude (1043 m above sea level) in the northwestern part, while the southeastern area is of lower altitude (660 $\mathrm{m}$ above sea level) [44]. The climate of Islamabad-Rawalpindi is humid subtropical, since both are located at the foot of the mountains.

The twin cities are well-planned and are thus distinct from other cities in the country that have historically evolved downtown areas, old cities, and urban slums. Despite being well-planned cities, they lack a proper waste disposal system even 50 years after establishment. Only $60 \%$ of the waste generated in the cities is collected by the Capital Development Authority (CDA) and Rawalpindi Waste Management Company [45,46]. The waste disposal method in the twin cities is open dumping without any gas collection or leachate management system for the safety of ground and surface water resources [47]. An existing dumping site, I-12, is located in a residential area next to a major government hospital, which is not ideal for waste disposal.

A huge amount of waste is dumped on the bed of the Soan river. Nullah Lai flows west of the city, entering from the southwest and joining the Soan River on the southern side. The Soan is the main stream draining Islamabad and the surrounding areas, which particularly affects the Dhok Chapper, Dhoke Ratta, Gulraiz Charistain Colony, Dhoke Hassu, and Nullah Lai. The Nullah Lai is a watercourse that transports a high amount of untreated community sewage and municipal solid waste along its path [48]. In addition, the main source of piped water is three dams, namely, the Khanpur dam, the Simly dam, and the Rawal dam. All except for Rawal dam are quite distant from the urban area of the twin cities and are less exposed to manmade contamination. However, the Rawal Dam is likely to be polluted with municipal waste.

Solid waste management is unsustainable in Islamabad-Rawalpindi as the local authorities fail to handle waste properly. The spreading of uncollected heaps of waste is visible almost everywhere, posing a major threat to public health and the quality of the local environment. There is a fundamental difference between the processes of waste collection and disposal adopted by most of the public and private agencies in the twin cities and the operationally available best practices accounting for sustainability and circular economy.

It is alarming that waste is typically discarded in an unauthorized way and that many residents of the metropolis do not dump their waste at the designated sites. Even the planned urban areas lack appropriate waste collection. Private service providers in the waste management sector operate either on a commercial basis where services are provided to those who demand it or as private operators who serve all residents of a locality and receive a subsidy from local municipal governments. In addition, source-segregation of waste materials among households prior to collection is unusual in the sample compared to in advanced countries, where waste is typically segregated and collected separately. In 
the twin cities, waste segregation at the source among households is lacking, and generated waste is jumbled in a single container.

In the twin cities, NOx and PM10 concentrations were found to be higher than the WHO guidelines. In Islamabad, the highest level of $\mathrm{CO}$ per hour was reported to be $3.3 \mathrm{ppm}$. These pollutants create a layer of smog that reduces the visibility of Margalla Hills (a suburb of Islamabad), showing the intensity of the city's pollution [49]. The $\mathrm{Pb}$ and $\mathrm{Zn}$ concentrations in waste were also found to be relatively higher than those of other components. The average concentrations of $\mathrm{Pb}$ were $3.9,3.2$, and $4.6 \mu \mathrm{g} / \mathrm{g}$ and the average concentrations of $\mathrm{Zn}$ were $6.6,5.3$, and $6.7 \mu \mathrm{g} / \mathrm{g}$ in Islamabad-Rawalpindi [50].

In addition, monsoons play a decisive role in evaluating the air quality in Islamabad due to weather conditions. The production and composition of leachate become worse during the monsoon season. Open dumping during the monsoon season triggers the highest output of leachate. Evidence shows that the post-monsoon period is more polluted than the pre-monsoon period, posing a threat to the local population. Similarly, compared to the pre-monsoon period, a higher level of PM10 was found to result in $43 \%$ more infant deaths and $41 \%$ more all-cause-mortality deaths in the post-monsoon period [51].

\section{Literature Review}

The existing SWM systems in developing countries have resulted in the mushrooming of unplanned dumpsites. Environmental governance of SWM is becoming the central component of a sound waste management policy that dominates the development discourse. Studies in the literature have focused primarily on the planning part, and very few studies have investigated the social and health costs of waste production and its disposal activities. The externality aspect of waste management makes it essentially a normative policy issue. The utility provider may recover the financial cost of the service from waste producers; however, it would be difficult to analysis this without calculating the cost of externalities.

The disposal of waste at landfill sites has an effect on people living in the site neighborhoods [52]. A study showed that $78 \%$ of participants living near a landfill site reported significant air pollution due to bad odors, and 56\% of those living near the landfill site expressed concerns for their health in the future. The prevalence of diarrhea in households was found to be $14.4 \%$ in a cross-sectional epidemiological analysis [19].

One of the most serious health consequences of dumping waste in inhabited areas is the risk of infectious diseases through water. Endemic zoonotic diseases, which are highly correlated with fecal material at waste disposal sites, are usually flushed away by rain into the surface or ground water, thus polluting the water source. Contaminated water contains fecal coliform counts of up to 15.25 MPN/100 mL of water, as compared to the recommended level of $0 \mathrm{MPN} / 100 \mathrm{~mL}$, which makes it extremely unhealthy for drinking purposes [28]; the health effects of hea MPN y metals in waste can also be life threatening and may range across headache, irritability, memory deterioration, diminished intellectual capacity, kidney damage disease, and liver and bioaccumulation leading to cancer $[53,54]$.

Substantial efforts have been made and many waste management programs have been introduced in order to mitigate the harmful effects of solid waste in developing countries over the past two decades [55]. Aside from national waste management plans, household SWM practices are becoming increasingly important as external costs of waste management grow [56].

Household participation can help in resource conservation and providing economic value through appropriate waste handling, which reduces environmental pollution and minimizes the financial costs of waste disposal. However, the participation rates of the community in waste management remain low in developing countries, perhaps due to a lack of understanding of segregation, individual behavior, or issues regarding awareness of the perceived benefit.

Source segregation is a key determinant of effective sustainable waste management [57]. The SW-Corp Strategic Plan 2014-2020 was introduced in Malaysia to implement the mandatory segregation of household waste, and it was found that segregation and re- 
duction of waste generation are efficient ways to minimize the harmful effects of waste disposal [58]. Household response to waste management can be two-pronged: mitigation and adaptation by taking protective measures. For mitigation purposes, the municipal agency can create enabling circumstances to reduce waste production and improve segregation and appropriate disposal. Households can take protective measures (safe drinking water, use of masks, etc.) to avoid the consequences of hazardous waste $[59,60]$. Therefore, direct and indirect effects on air, water quality, and health can also be mitigated by adopting an appropriate waste management system that essentially requires institutional commitment and a legal framework [61]. Table 1 summarizes the literature related to solid waste and its health impacts.

Table 1. Summary of literature related to the health impacts of solid waste.

\begin{tabular}{|c|c|c|}
\hline Authors & Objective of Study & Results \\
\hline [52] & $\begin{array}{l}\text { Disposal of waste in landfill } \\
\text { has an impact on residents } \\
\text { living closer to it }\end{array}$ & $\begin{array}{l}78 \% \text { of participants living closer } \\
\text { to the landfill site indicated } \\
\text { serious contamination of } \\
\text { air quality }\end{array}$ \\
\hline [19] & $\begin{array}{l}\text { Cross-sectional } \\
\text { epidemiological study }\end{array}$ & $\begin{array}{l}\text { Results revealed that } \\
\text { households suffer from } \\
\text { diarrheic disease because of } \\
\text { poor sanitation }\end{array}$ \\
\hline [28] & $\begin{array}{l}\text { Poor waste management and } \\
\text { water contamination }\end{array}$ & $\begin{array}{l}\text { Poor waste management has } \\
\text { adverse effects on human health }\end{array}$ \\
\hline [53] & $\begin{array}{l}\text { Cadmium exposure and } \\
\text { liver disease }\end{array}$ & $\begin{array}{l}\text { Causes kidney damage disease } \\
\text { and liver and bioaccumulation } \\
\text { that leads to cancer }\end{array}$ \\
\hline [54] & $\begin{array}{l}\text { Effects of toxic metals } \\
\text { on health }\end{array}$ & $\begin{array}{l}\text { Cause headache, irritability, } \\
\text { memory deterioration, and } \\
\text { diminished intellectual capacity }\end{array}$ \\
\hline This study & $\begin{array}{l}\text { Assessment of the health } \\
\text { damages incurred in } \\
\text { heterogeneous households } \\
\text { due to poor waste } \\
\text { management }\end{array}$ & 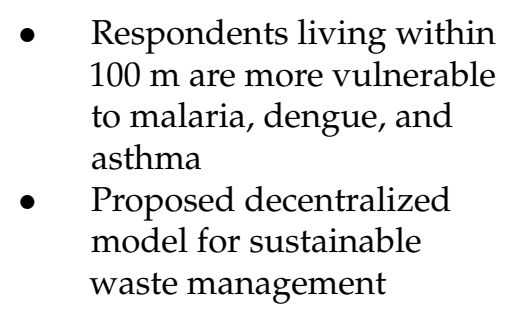 \\
\hline
\end{tabular}

\section{Study Design and Sample Size}

In this study, we employed a cross-sectional quantitative dataset obtained from the residents of the selected localities of the twin cities of Rawalpindi and Islamabad through a structured questionnaire. The questionnaire was self-administered and paraphrased in the Urdu language as most of the respondents would not be able to answer in English. The questionnaire was based on a literature review and in consultation with sectoral experts before and after pretesting.

The study presumed that waste is dumped at a site in each locality. Households were assumed to be heterogeneous in their choice of residence and were divided into two groups-those living near the dumpsite (within a range of $100 \mathrm{~m}$ to $500 \mathrm{~m}$ radius) and those living away from the dumpsite (more than $500 \mathrm{~m}$ away). Urban poor in the twin cities face many barriers to accessing solid waste management services and live in an unhealthy environment compared to the residents of wealthy communities. The predominant practice of poor communities is open dumping in empty plots and beside water streams (nullahs). 
Nullahs originate from the river. A huge water stream flows near the residential area; it is not only natural-it is also used for sewage purposes in the twin cities.

Solid waste services in poor communities are not considered to be the main service delivery component. Both types of households are distinct in their degree of exposure to pollution and may be at varying risk of diseases. The survey included questions about eight reported toxic exposure symptom variables across households: (1) diarrhea, (2) malaria, (3) dengue, (4) asthma, (5) skin problems/irritation, (6) cholera, (7) typhoid, and (8) fatigue.

Multistage random sampling was employed for data collection. In the first stage, we randomly selected certain residential areas. In the second stage, houses within a street were randomly chosen in a particular sector. In the third stage, the sample was divided into 35 sectors and towns, and 24 households from each sector were selected for interviews. Selected sites were further divided into 17 locations close to dumpsites and 18 residential locations away from dumpsites. In the final stage of the analysis, 850 households were interviewed. The data were input into SPSS to generate descriptive statistics, and then frequency and correlation tests were conducted.

It was hypothesized that both the waste collection services and waste-related environmental health awareness vary in different localities. Generally, each locality consists of households with similar income, which can be an important factor revealing the capacity of households to successfully implement solid waste management strategies to support municipal corporations. This leads to disparities in the attitude of householders to handling and segregating waste, as well as their participation in waste reduction programs, participation in recycling, and demand for collection services. Figure 1 gives a glimpse of the survey site and properly numbered sampling basis.

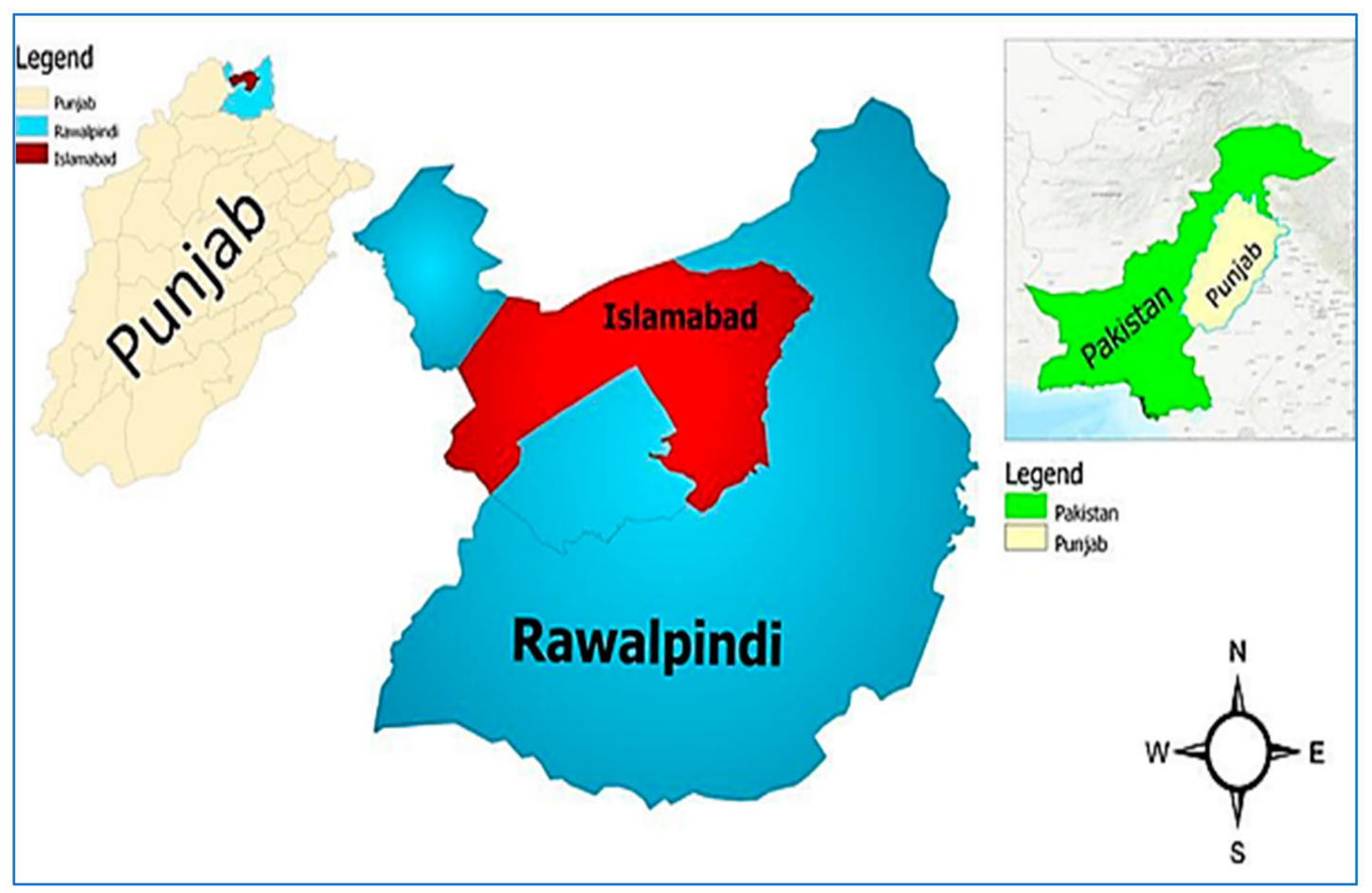

(a)

Figure 1. Cont. 


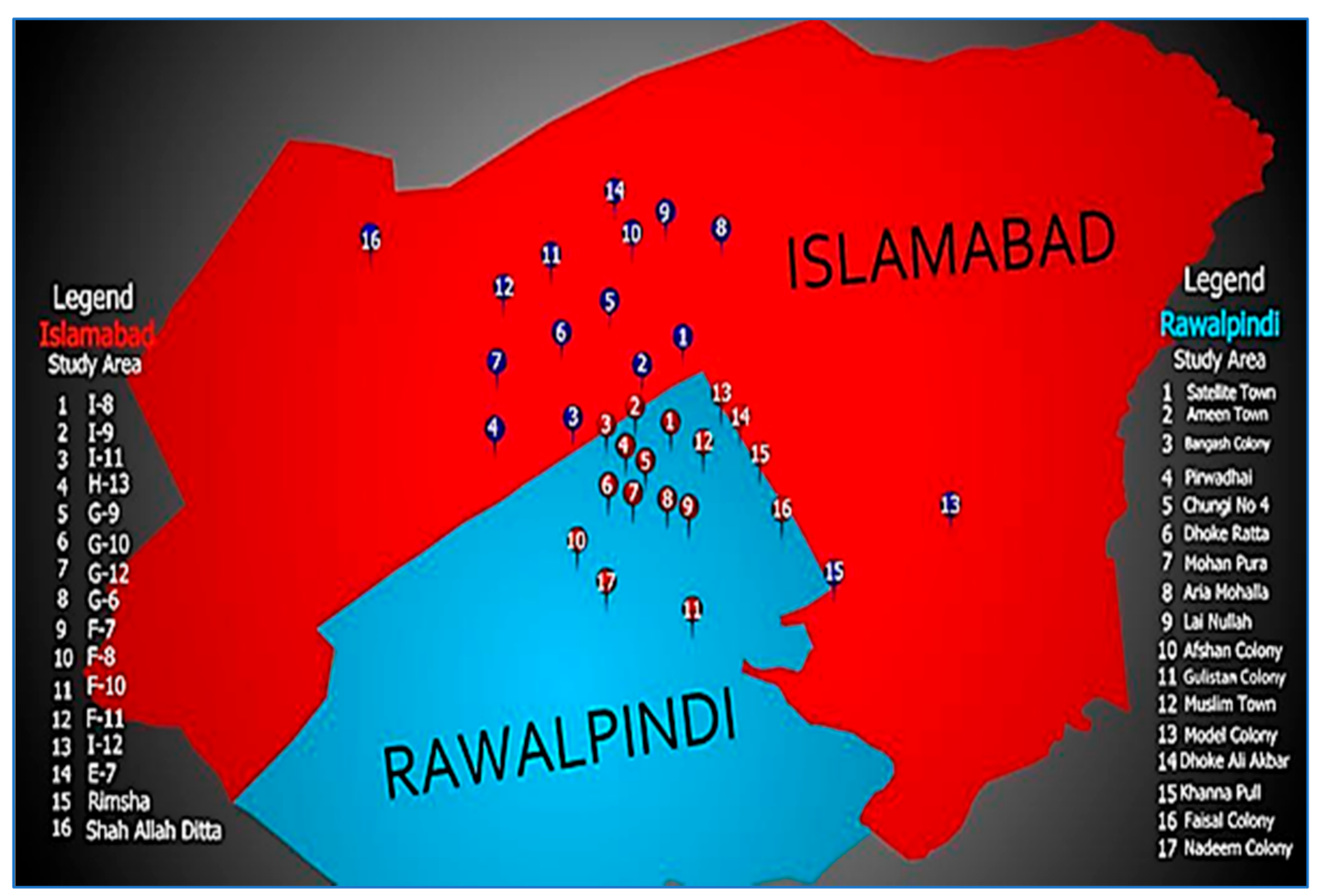

(b)

Figure 1. (a) Map of the twin cities and (b) locus of sampling clusters.

\subsection{Statistical Analysis}

The demographic statements included in the survey were gender, age, education, and income. The majority $(64.8 \%)$ of the respondents in the sample were women, as shown in Table 2. The education levels of households were erratic, as we found a dip in the case of secondary education vis-à-vis the lower and higher education levels. A similar data trend was exhibited for monthly family income, where the lowest and the highest income groups had the highest frequencies in relation to other inhabitants of the selected sample, as can be seen in Table 2. Correlations between all items are presented in the Appendix A.

Table 2. Social-economic information on the respondents.

\begin{tabular}{|c|c|c|c|c|c|}
\hline \multirow{2}{*}{ Gender } & \multicolumn{5}{|c|}{ Age } \\
\hline & $15-20$ & $21-30$ & $31-40$ & $41-50$ & $>51$ \\
\hline Female & 153 & 221 & 119 & 47 & 11 \\
\hline Male & 92 & 94 & 109 & 3 & 1 \\
\hline Education & $<30 \mathrm{k}$ & $31 \mathrm{k}-50 \mathrm{k}$ & $\begin{array}{c}\text { Income } \\
51 \mathrm{k}-70 \mathrm{k}\end{array}$ & $51 \mathrm{k}-70 \mathrm{k}$ & $71 \mathrm{k}-1-\mathrm{lac}$ \\
\hline Illiterate & 92 & 57 & 21 & 7 & 26 \\
\hline Primary & 30 & 10 & 9 & 3 & 5 \\
\hline Secondary & 70 & 41 & 38 & 13 & 46 \\
\hline Higher & 29 & 38 & 46 & 19 & 56 \\
\hline Professional & 27 & 32 & 28 & 24 & 73 \\
\hline
\end{tabular}

Source: Author's calculation.

\subsection{Waste Generation and Composition}

In the present study (Table 3), biodegradable waste (mainly kitchen waste) was found to contribute most $(45.5 \%)$ to the generation of household solid waste (HSW). These results are consistent with findings from several other developing countries, including Nigeria [55]. Kitchen waste typically becomes moldy and produces strong odors. Proper 
treatment of waste materials is therefore essential for the maintenance of a healthy and balanced environment.

Table 3. Waste composition.

\begin{tabular}{ccccc}
\hline Index & Item & Sample & Percentage & Kg/Person/Day \\
\hline \multirow{3}{*}{$\begin{array}{c}\text { Waste } \\
\text { composition }\end{array}$} & Plastic & $342 \mathrm{~kg}$ & 18.46 & $0.40 \mathrm{~kg} /$ day \\
\cline { 2 - 5 } & Organic & $842 \mathrm{~kg}$ & 45.46 & $0.99 \mathrm{~kg} /$ day \\
\cline { 2 - 5 } & Glass & $279 \mathrm{~kg}$ & 15.06 & $0.32 \mathrm{~kg} /$ day \\
\cline { 2 - 5 } & Paper & $172 \mathrm{~kg}$ & 9.28 & $0.20 \mathrm{~kg} /$ day \\
\cline { 2 - 5 } & Other & $217 \mathrm{~kg}$ & 11.71 & $0.25 \mathrm{~kg} /$ day \\
\cline { 2 - 5 } & Total & $1852 \mathrm{~kg}$ & 100 & $2.17 \mathrm{~kg} /$ day \\
\hline
\end{tabular}

Source: Author's calculation.

The survey results revealed that each person produces $2.17 \mathrm{~kg}$ of waste per day in the study area of twin cities in Pakistan, out of which $0.40 \mathrm{~kg} /$ day is plastic, $0.99 \mathrm{~kg} /$ day is organic components, and 0.32 and $0.20 \mathrm{~kg} /$ day are glass and paper, respectively. This result is similar to the findings of previous studies in Beijing, China (0.8 kg/cap/day); Ambon, Indonesia ( $0.9 \mathrm{~kg} / \mathrm{cap} /$ day); and Lahore, Pakistan (0.84 kg/cap/day) [39]. Various factors can affect household waste generation, such as family size, education level, and monthly income [62].

Only $51.4 \%$ of households in the study area have access to waste collection services. In addition, the solid waste disposal methods used by households in the survey area are quite unsatisfactory. The most common means of waste disposal were a street-side container and door-to-door collection, and $29.3 \%$ of households dumped their waste into containers. Respondents stated that containers overflow and create a breeding ground for mosquitoes and rodents. Another $22.2 \%$ used a door-to-door collection service, while $17.6 \%$ of households dumped their waste directly into empty plots, and $21.8 \%$ of households dumped their waste into water bodies such as sewage streams (nullahs). Burning of waste was reported by $9.1 \%$ of households. Households do not recycle waste in the twin cities of Pakistan - the results showed that collected waste is mostly not segregated $(75.9 \%)$.

\subsection{Awareness of Solid Waste Management}

The results demonstrate that 58 percent $(n=492)$ of the survey participants were not aware of the hazardous effects of solid waste, compared to 42 percent $(n=359)$ who were aware of them (Figure 2).

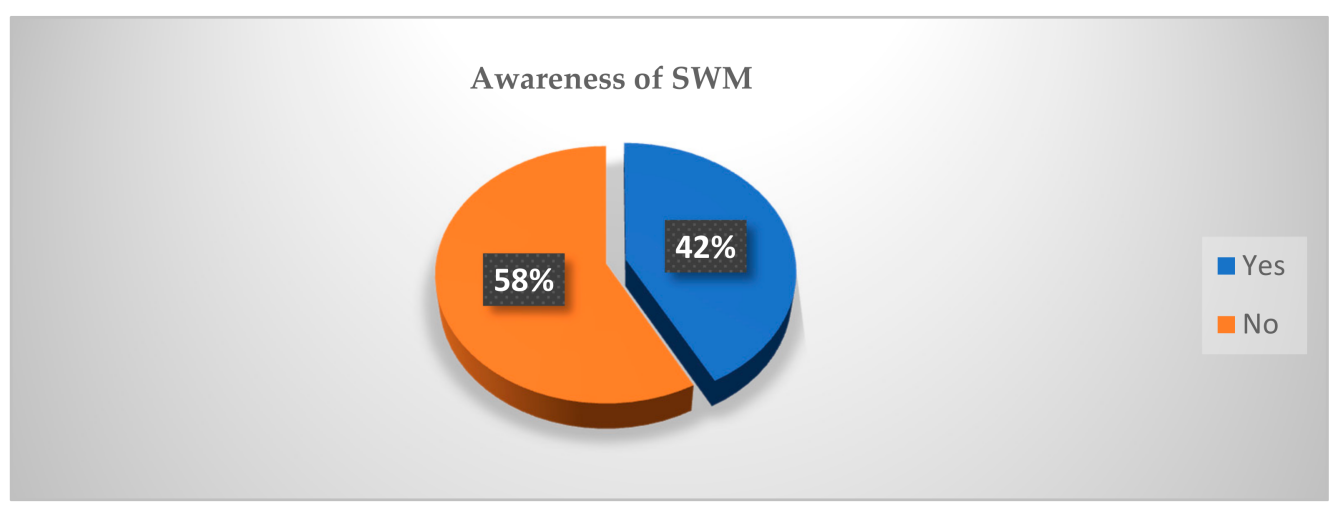

Figure 2. Household awareness of solid waste management (SWM) practices. 


\subsection{Interconnection between Solid Waste and Diseases in Islamabad-Rawalpindi}

In the present study, $21 \%$ of households reported that no member of the household had suffered from the mentioned diseases or disorders during the past 12 months as a result of their exposure to hazardous waste. According to the responses, $31 \%$ of households had a member who suffered from diarrhea, $13 \%$ from dengue, $20 \%$ from malaria, $13 \%$ from cholera, $6 \%$ from skin infections, $9 \%$ from asthma, $6 \%$ from typhoid, and $2 \%$ from fatigue (Figure 3), all of which can be linked to various environmental and hygiene factors, including poor sanitation. In low-income, high-density areas, the number of different types of diseases per household has increased in the last year. Therefore, household risk perception needs to be addressed. It is suggested that awareness of a health hazard leads to a household's willingness to clean exposure-relevant contaminated sites, thereby leading to a reduction in health hazards [63].

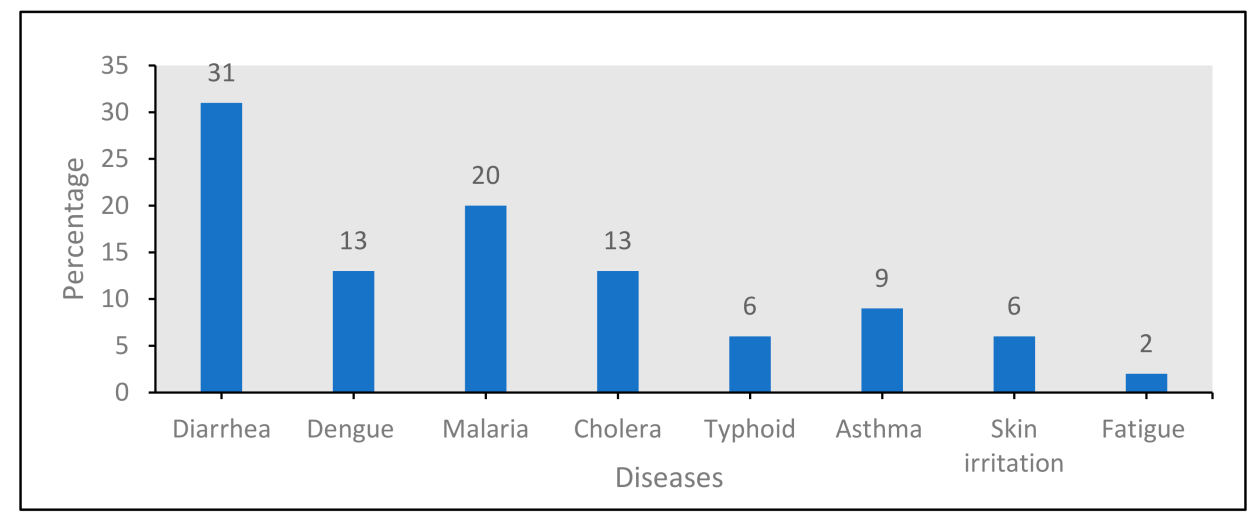

Figure 3. Household disease burden declared by respondents.

\subsection{Interconnection between Distance from Dumpsite and Diseases}

The households analyzed in this study can be divided into clusters based on their geographical distance from a dumpsite. Based on our survey results (see Figure 4), people living close to dumpsites are more likely to be exposed to pollution such as air pollution, toxic gases from rotten trash, contaminated tap water, and $\mathrm{Cu}, \mathrm{Mg}$, and $\mathrm{Sb}$ contamination. These hazards can cause a variety of diseases, as shown in Figure 2. Respondents living within $100 \mathrm{~m}$ are more vulnerable to malaria, dengue fever, and asthma, and $31 \%$ of respondents suffering from different waste-related diseases lived within $100 \mathrm{~m}$, compared to $16 \%$ living $\geq 500 \mathrm{~m}$ away. Moreover, $29 \%$ of those living in the $101-200 \mathrm{~m}$ range and $17 \%$ living in the 201-300 $\mathrm{m}$ range reported facing illnesses.

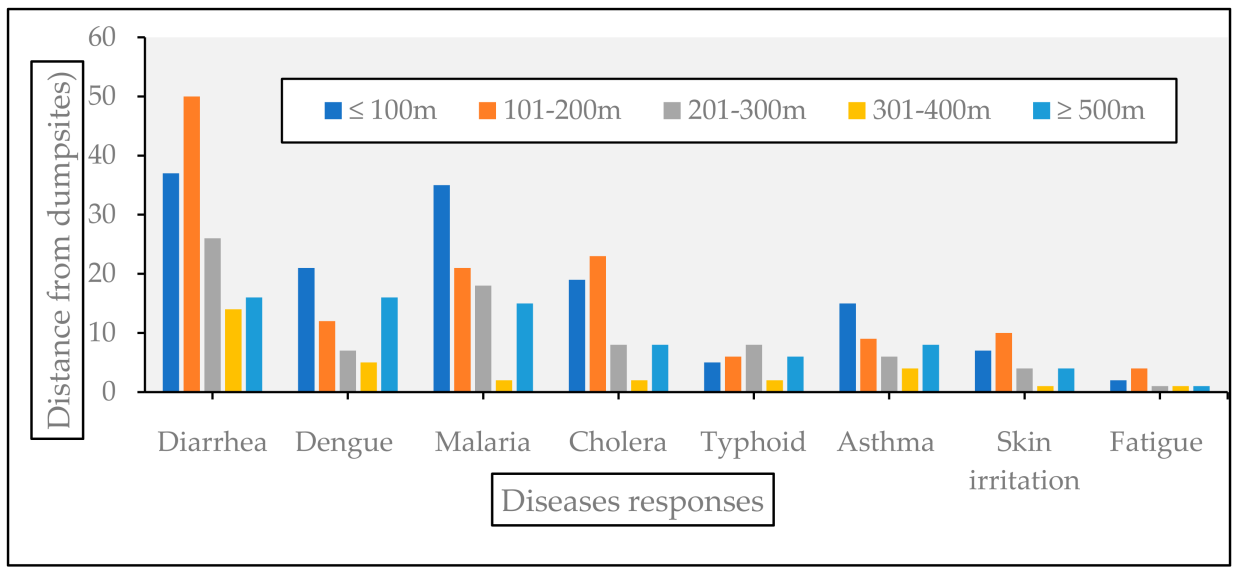

Figure 4. Interrelation between diseases and distance from a dumpsite. 


\subsection{Government Policy Instruments}

Households can be induced to segregate waste by monetary rewards, coercion, and penalties levied by the government. As shown in Figure 5, our results revealed that a subsidized waste management service is an optimal solution to be provided either by local government or by outsourcing. Based on our survey data, $32.7 \%$ of households were strongly in favor of incentive-based waste management policies. As a result, the Government will be able to allocate its resources in an appropriate manner to boost societal standards and benefits, as well as carry out targeted interventions to encourage households to segregate their garbage.

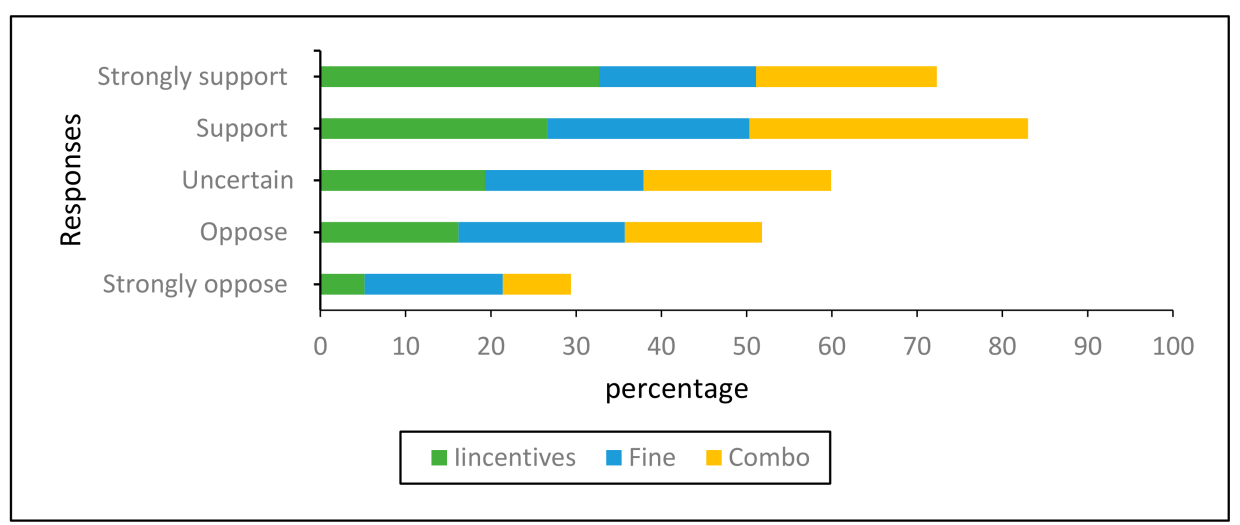

Figure 5. Government policy instruments for SWM.

\section{A Proposed Plan for an Improved Waste Management System}

Sustainable waste management (SWM) is a key concept of circular economy that opens up a multitude of opportunities. Environmentally friendly waste management starts right from its generation. In exacting frameworks, waste management is a "value chain" that involves the treatment, reuse, and disposal and recycling of various waste streams that provide economic incentives; however, current frameworks lack descriptions of the external costs and the related economic players, as well as why economic agents should cooperate to achieve an optimal solution.

For sustainable waste management, it is necessary to know where we are before we can plan the route to where we wish to be. Figure 6 highlights and compares the adopted model vis-à-vis the desired process. Figure 6 demonstrates a comprehensive SWM strategy with clearly established goals and priorities that transforms the current infrastructure to a decentralized model for sustainable waste management. The proposed model shows that an optimal model for SWM includes devolving collection, which would integrate households into the waste management process, and delegating treatment, which incentivizes municipality authorities to install appropriate technology, thus controlling the external costs and the number of landfill sites built and promoting monitoring. A coherent national legislative framework is designed and enforced in addition to comprehensible monitoring at every step. 


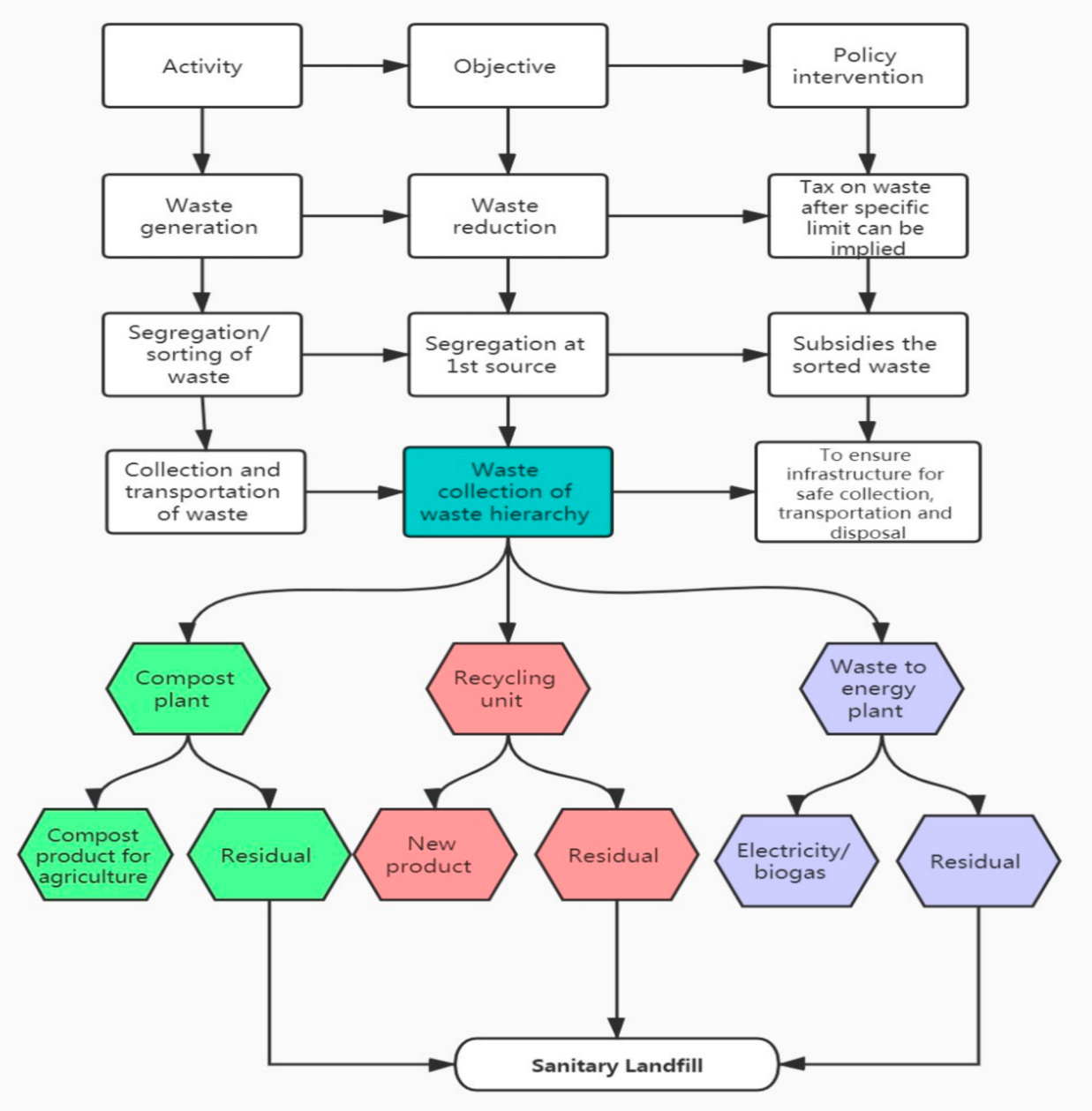

Figure 6. The architectural View of Economic Planning for an Integrated MSW system.

In the given scenario, three types of economic agents work together, namely, households, waste collection companies, and the government. The choice of a household between external costs and abatement activities depends on the price ratio and the marginal utility they gain. The proposed plan offers a normative model of individual behavior towards waste disposal that can reduce the associated externalities of waste in the form of health damages and can recover resources.

In additional, the framework provides useful insights for municipal authorities, enabling local administrations to share the responsibilities associated with solid waste management practices, reducing local administrations' vulnerability and diminishing regional economic disparities. Integrating local populations, community-based organizations (CBOs), and non-governmental organizations (NGOs) into the operational scheme would enable the sharing of financial burdens and more appropriate waste management.

In addition, the approach proposed herein offers numerous policy options for integrating authorities and shows how these policies assist in achieving desired outcomes for sustainable waste management. Each operation is connected to the defined goals and policy recommendations, and it helps in achieving the desired solution for sustainability.

\section{Conclusions and Policy Implications}

This study identified the health impacts of waste disposal sites. According to our study results, the health status of residents in Islamabad-Rawalpindi varies depending on their proximity to a dumpsite. Households living closer to a dumpsite are more vulnerable to various risk factors, such as air pollution, water contamination, and mosquitoes and 
rodents, all of which can result in a number of hazards and should be taken seriously by the local authorities.

This empirical study offers policy guidance to policy-makers in order to make their intervention plans more cost-effective in reducing the negative externalities of waste. Improvements in waste collection services can set forth a huge chain of beneficial outcomes. Improvements in human health are, of course, the most widely predicted result of waste management interventions. Increased availability of waste collection services reduces the incidence of waste-related diseases, while improvements in the quality of water lower the incidence of waterborne diseases.

The analysis of waste-related illness in the present study repeatedly demonstrated the importance of safe and adequate waste collection and disposal services in improving the status of households in Pakistan who are vulnerable to the occurrence of such illnesses. The results highlight the significance of overall infrastructure variables such as garbage removal facilities, water sources, and the usage of contaminated water, which are not always within the control of the specific household. As a consequence, community and government participation is needed. In addition, the results also indicate extreme demand for waste management services as only $51.4 \%$ of residents in the study area availed themselves of waste collection services. The results provide food for thought to local bodies in terms of meeting the unsustainable demand for waste collection services.

Author Contributions: T.A.-conceptualization, methodology, formal analysis, original draft preparation, study design, methodology, review and editing, supervision, project administration, methodology, data curation, validation, and formal analysis. F.J.-supervision, review and editing. All authors have read and agreed to the published version of the manuscript.

Funding: This research was funded by the National University of Sciences and Technology (NUST), Pakistan (Grant 633 USD).

Institutional Review Board Statement: So far, Pakistan does not have an institutional review board or national ethical guidelines for Economics studies. The study therefore adhered to existing research ethics principles such as obtaining verbal consent to participate in research, retaining personal informal privacy, and allowing participants to withdraw their consent if they so wished at any point. In addition, no personal information was used in this analysis. Participants, who provided information related to solid waste generation and related information, were used in this research.

Informed Consent Statement: Informed consent was obtained from all subjects involved in the study.

Data Availability Statement: Data published in this study are available on request from the corresponding author. The data are not publicly available due to the policy of the research project.

Conflicts of Interest: The authors declare no conflict of interest.

\section{Appendix A}

\section{Appendix A.1. QUESTIONNAIRE}

We are here to conduct a study on solid-waste-management-related issues. You are invited to take part in this research project. Please note that your participation is entirely voluntary, and deciding not to participate will not affect your relationship with the researchers or associated organizations. If you agree to participate, you will be interviewed using a questionnaire. You may choose not to answer some of the questions or all if you feel so inclined, but your response will be a very important source of information on sustainably managing waste and the drinking water supply in your area. It will take approximately $30 \mathrm{~min}$, and you may of course decide to stop the interview at any point. You have been selected as a resident of Islamabad-Rawalpindi Metro. The purpose of this research is to collect information on various aspects of solid waste management. This research aims to raise awareness about the issues associated with solid waste and to provide valuable information to the municipality and relevant policy-makers to manage solid waste in a sustainable way. The questionnaire contains alternative policy options related to municipal solid waste management and household information. There are no right or wrong answers, 
and the choices you are going to make are useful for future planning and making relevant policies for the effective management of solid waste. We are interested in your opinion and we will take handwritten notes on your responses on a questionnaire sheet.

We would like to assure you that your response will be completely anonymous, and only aggregated results of the questionnaires will be used for disseminating and publishing research outcomes.

Thank you very much.

Would you like to participate in the survey? [ ] Yes $=1 \mathrm{No}=0$ (find next household).

\section{Appendix A.2. INSTRUCTIONS FOR ENUMERATORS}

- Multiple ticks $(\sqrt{ })$ are allowed; always ask if the respondent wants to tick more than one option.

- Please fill the blank with an appropriate entry and do not leave it empty.

- When consecutive numeric entries show inconsistency and do not make sense, please confirm the answers or explain the questions again, if the respondent is not clear.

Appendix A.3. PERSONAL INFORMATION OF THE RESPONDENT

\begin{tabular}{cccc}
\hline $\begin{array}{c}\text { Respondent Name } \\
\text { (optional) }\end{array}$ & P11 & Area Name & P12 \\
\hline $\begin{array}{c}\text { Respondent Cell } \\
\text { No. (optional) }\end{array}$ & P21 & $\begin{array}{c}\text { Household head } \\
\text { or not? }\end{array}$ & P22 \\
\hline
\end{tabular}

Appendix A.3.1. A. Household Basic Information

Household Size:

Household Head

\begin{tabular}{rrrrrrc}
\hline Sr. \# & $\begin{array}{l}\text { Relationship } \\
\text { with } \text { HH }^{\text {1* }}\end{array}$ & Gender & Age & $\begin{array}{c}\text { Years of } \\
\text { Schooling }\end{array}$ & Occupation ${ }^{2 *}$ \\
\hline a11 & 1 & a12 & a13 & a14 & a15 & a16 \\
a21 & 2 & a22 & a23 & a24 & a25 & a26 \\
a31 & 3 & a32 & a33 & a34 & a35 & a36 \\
a41 & 4 & a42 & a43 & a44 & a45 & a46 \\
a51 & 5 & a52 & a53 & a54 & a55 & a56 \\
a61 & 6 & a62 & a63 & a64 & a65 & a66 \\
a71 & 7 & a72 & a73 & a74 & a75 & a76 \\
a81 & 8 & a82 & a83 & a84 & a85 & a86 \\
a91 & 9 & a92 & a93 & a94 & a95 & a96 \\
a101 & 10 & a102 & a103 & a104 & a105 & a106 \\
a111 & 11 & a112 & a113 & a114 & a115 & a116 \\
a121 & 12 & a122 & a123 & a124 & a125 & a126 \\
a131 & 13 & a132 & a133 & a134 & a135 & a136 \\
a141 & 14 & a142 & a143 & a144 & a145 & a146 \\
a151 & 15 & a152 & a153 & a154 & a155 & a156 \\
\hline
\end{tabular}

${ }^{1 *}$ Household head $=1$, Spouse $=2$, Son $/$ Daughter $=3$, Grandchild $=5$, Brother $/$ Sister $=6$, Head parent $=7$, Other relative $=8 .{ }^{2 *}$ Housewife $=1$, Unemployed $=2$, Employed in Government $=3$, Employed in private sector $=4$, Business $=5$, Employed in formal sector (contractual) $=6$, Employed in informal sector $=7$, Retired $=8$, Earnings from abroad $=9$, Student $=10$, Technician $=11$, Daily wages $=12$, Other $($ specify $)=13$. 
Appendix A.3.2. B. Waste Disposal

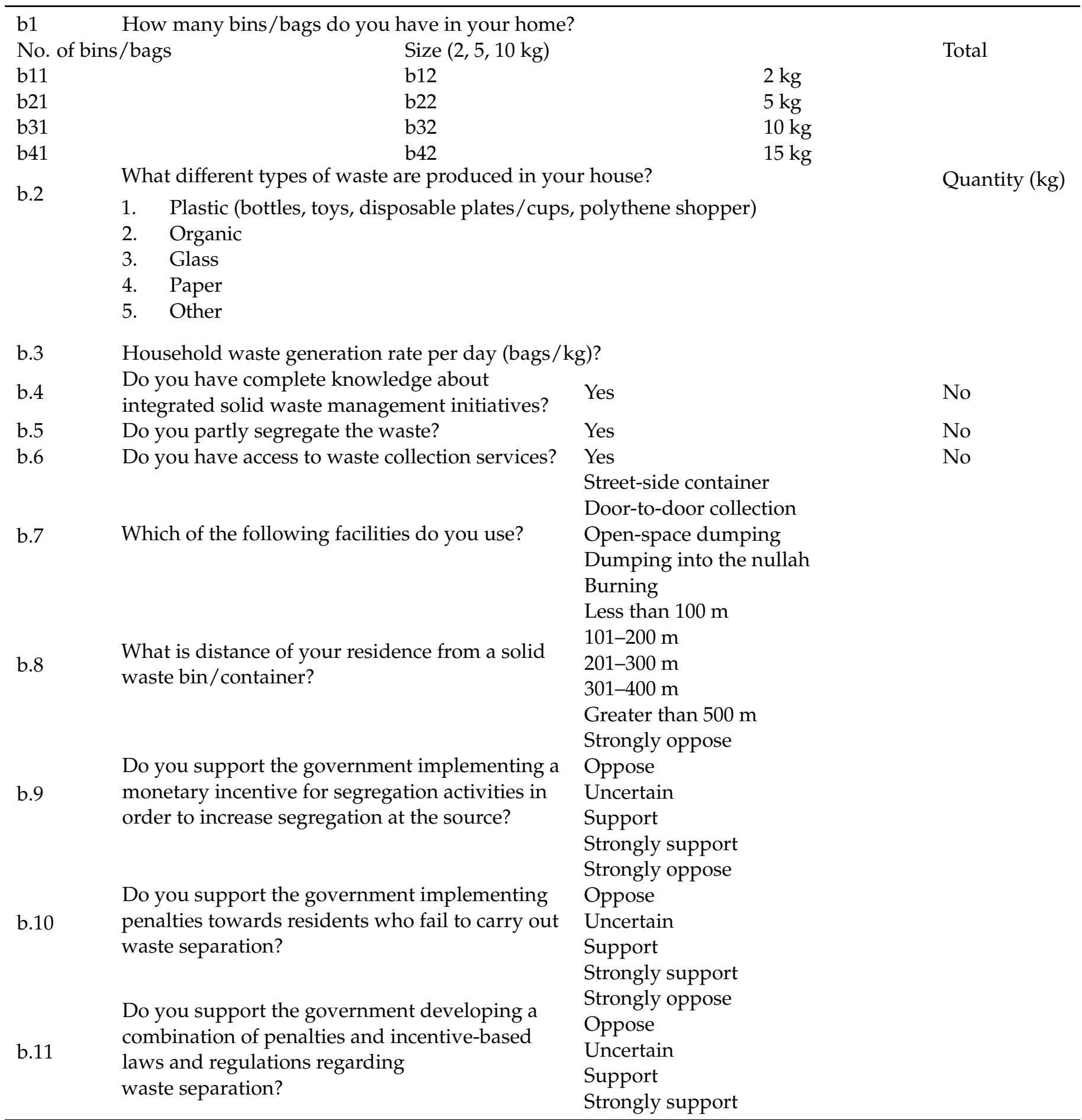

Appendix A.3.3. C. Health Status and Waste Disposal

How frequently do you or your family members fall sick due to environmental issues?
Once a month

Once twice months

Once in three months Once in months greater than six months 
c.2: Has anyone in your household suffered from any of these listed diseases during the last six weeks, which can be attributed to dumpsites/non-dumpsites?

\begin{tabular}{|c|c|c|c|c|c|c|}
\hline S. No & $\begin{array}{l}\text { Waste-/Water-Borne } \\
\text { Diseases }\end{array}$ & $\begin{array}{l}\text { HH, s } \\
\text { Code }\end{array}$ & $\begin{array}{l}\text { No. of Days } \\
\text { Sick }\end{array}$ & $\begin{array}{l}\text { No. of Days } \\
\text { Unable to o to } \\
\text { Work/School }\end{array}$ & $\begin{array}{l}\text { No. of } \\
\text { Hospital } \\
\text { Visits }\end{array}$ & $\begin{array}{l}\text { Expenses for } \\
\text { Treatment } \\
\text { (RS) }\end{array}$ \\
\hline c. 21 & Diarrhea & & & & & \\
\hline c. 22 & Dengue & & & & & \\
\hline c. 23 & Malaria & & & & & \\
\hline c. 24 & Typhoid & & & & & \\
\hline c. 25 & Cholera & & & & & \\
\hline c. 26 & Asthma & & & & & \\
\hline c. 27 & Skin disease & & & & & \\
\hline c. 28 & Fatigue & & & & & \\
\hline c. 29 & $\begin{array}{l}\text { Not caught any } \\
\text { disease }\end{array}$ & & & & & \\
\hline
\end{tabular}

Note: In case of an employed person falling sick, link with family table. 
Appendix A.3.4. Correlations of the Constructs

\begin{tabular}{|c|c|c|c|c|c|c|c|c|c|c|}
\hline & Methods & Incentives & Fine & Combo & Diseases & Distance & Access & Segregation & Awareness & Total \\
\hline Methods & 1 & & & & & & & & & \\
\hline Incentives & $\begin{array}{c}0.138 * * \\
(0.000)\end{array}$ & 1 & & & & & & & & \\
\hline Fine & $\begin{array}{c}-0.142 * * \\
(0.000)\end{array}$ & $\begin{array}{l}0.382^{* *} \\
(0.000)\end{array}$ & 1 & & & & & & & \\
\hline Combo & $\begin{array}{c}0.025 \\
(0.472)\end{array}$ & $\begin{array}{c}0.542 \text { ** } \\
(0.76)\end{array}$ & $\begin{array}{l}0.509 * * \\
(0.000)\end{array}$ & 1 & & & & & & \\
\hline Diseases & $\begin{array}{c}-0.226^{* *} \\
(0.000)\end{array}$ & $\begin{array}{c}-0.075 \text { * } \\
(0.029)\end{array}$ & $\begin{array}{l}-0.033 \\
(0.331)\end{array}$ & $\begin{array}{l}-0.033 \\
(0.343)\end{array}$ & 1 & & & & & \\
\hline Distance & $\begin{array}{c}-0.321 \text { ** } \\
(0.000)\end{array}$ & $\begin{array}{c}-0.102 * * \\
(0.003)\end{array}$ & $\begin{array}{l}0.165^{* *} \\
(0.000)\end{array}$ & $\begin{array}{l}-0.019 \\
(0.586)\end{array}$ & $\begin{array}{l}0.587^{* *} \\
(0.000)\end{array}$ & 1 & & & & \\
\hline Access & $\begin{array}{l}0.754^{* *} \\
(0.000)\end{array}$ & $\begin{array}{l}0.179 * * \\
(0.000)\end{array}$ & $\begin{array}{l}-0.036 \\
(0.298)\end{array}$ & $\begin{array}{c}0.032 \\
(0.347)\end{array}$ & $\begin{array}{c}-0.257^{* *} \\
(0.000)\end{array}$ & $\begin{array}{c}-0.367^{* *} \\
(0.000)\end{array}$ & 1 & & & \\
\hline Segregation & $\begin{array}{l}0.196 \text { ** } \\
(0.000)\end{array}$ & $\begin{array}{c}0.043 \\
(0.214)\end{array}$ & $\begin{array}{l}-0.001 \\
(0.981)\end{array}$ & $\begin{array}{l}-0.066 \\
(0.056)\end{array}$ & $\begin{array}{l}-0.052 \\
(0.130)\end{array}$ & $\begin{array}{c}-0.46 \\
(0.181)\end{array}$ & $\begin{array}{c}0.245^{* *} \\
(0.000)\end{array}$ & 1 & & \\
\hline Awareness & $\begin{array}{c}-0.068 * \\
(0.047)\end{array}$ & $\begin{array}{c}0.002 \\
(0.963)\end{array}$ & $\begin{array}{c}0.056 \\
(0.101)\end{array}$ & $\begin{array}{l}-0.005 \\
(0.876)\end{array}$ & $\begin{array}{c}0.031 \\
(0.362)\end{array}$ & $\begin{array}{c}0.055 \\
(0.108)\end{array}$ & $\begin{array}{l}-0.057 \\
(0.097)\end{array}$ & $\begin{array}{l}-0.026 \\
(0.450)\end{array}$ & 1 & \\
\hline Total & $\begin{array}{l}0.332 * * \\
(0.000)\end{array}$ & $\begin{array}{l}0.622 \text { ** } \\
(0.000)\end{array}$ & $\begin{array}{l}0.627 * * \\
(0.000)\end{array}$ & $\begin{array}{l}0.655 * * \\
(0.000)\end{array}$ & $\begin{array}{l}0.072 * * \\
(0.035)\end{array}$ & $\begin{array}{c}0.030 \\
(0.380)\end{array}$ & $\begin{array}{l}0.322 * * \\
(0.000)\end{array}$ & $\begin{array}{l}0.155 * * \\
(0.000)\end{array}$ & $\begin{array}{l}0.148 * \\
(0.000)\end{array}$ & 1 \\
\hline
\end{tabular}

Note: ${ }^{* *}$ and ${ }^{*}$ indicate significance at $1 \%$ and $5 \%$, respectively, and squared correlations are in parentheses.

\section{References}

1. Ashraf, U.; Hameed, I.; Chaudhary, N.M. Solid waste management practices under public and private sector in Lahore, Pakistan. Bull. Environ. Stud. 2016, 1, 98-105.

2. Kumar, S.; Pandey, A. Current developments in biotechnology and bioengineering and waste treatment processes for energy generation: An introduction. In Current Developments in Biotechnology and Bioengineering; Elsevier: Amsterdam, The Netherlands, 2019; pp. 1-9.

3. Lagerkvist, A.; Dahlen, L. Solid waste generation and characterization. In Recovery of Materials and Energy from Urban Wastes: A Volume in the Encyclopedia of Sustainability Science and Technology, 2nd ed.; Springer: Cham, Switzerland, 2019; pp. 7-20.

4. Serge Kubanza, N.; Simatele, M.D. Sustainable solid waste management in developing countries: A study of institutional strengthening for solid waste management in Johannesburg, South Africa. J. Environ. Plan. Manag. 2020, 63, 175-188. [CrossRef]

5. Kinnaman, T.C.; Fullerton, D. Garbage and recycling with endogenous local policy. J. Urban Econ. 2000, 48, 419-442. [CrossRef]

6. Andreoni, J.; Levinson, A. The simple analytics of the environmental Kuznets curve. J. Public Econ. 2001, 80, 269-286. [CrossRef]

7. Chalkias, C.; Lasaridi, K. A GIS based model for the optimization of municipal solid waste collection: The case study of Nikea, Athens, Greece. WSEAS Trans. Environ. Dev. 2009, 1, 11-15.

8. Ogra, A. Logistic Management and Spatial Planning for Solid Waste Management Systems Using Geographical Information System. Available online: https://www.researchgate.net/publication/235979174_Logistics_Management_and_Spatial_Planning_ for_Solid_Waste_Management_System_using_Geographic_Information_System (accessed on 2 March 2021).

9. Bezama, A.; Agamuthu, P. Addressing the Big Issues in Waste Management. Waste Manag. Res. 2019, 37, 1-3. [CrossRef]

10. Nguyen, P.T.; Matsui, Y.; Fujiwara, T. Assessment of Plastics Waste Generation and Its Potential Recycling of Household Waste in Can-Tho City, Vietnam. Environ. Monit. Assess. 2011, 175, 23-35.

11. Tadesse, M.L.; Kumie, A. Healthcare waste generation and management practice in government health centers of Addis Ababa, Ethiopia. BMC Public Health 2014, 14, 1221. [CrossRef]

12. Aatamila, M.; Verkasalo, P.K.; Korhonen, M.J.; Viluksela, M.K.; Pasanen, K.; Tiittanen, P.; Nevalainen, A. Odor Annoyance near Waste Treatment Centres: A Population-Based Study in Finland. J. Air Waste Mgt. Assoc. 2010, 60, 412-418. [CrossRef] [PubMed]

13. Grossman, M. On the concept of health capital and the demand for health. J. Political Econ. 1972, 80, 223-255. [CrossRef]

14. Giusti, L. A Review of Waste Management Practices and Their Impact on Human Health. Waste Mgt. 2009, 29, 2227-2239. [CrossRef]

15. Habib, M.S.; Sarkar, B. An Integrated Location-Allocation Model for Temporary Disaster Debris Management under an Uncertain Environment. Sustainability 2017, 9, 716. [CrossRef]

16. Nabegu, A.B. An Analysis of Municipal Solid Waste in Kano Metropolis. J. Hum. Ecol. 2010, 31, 111-119. [CrossRef]

17. Nwanta, J.A.; Ezenduka, E. Analysis of Nsukka Metropolitan Abattoir Solid Waste in South Eastern Nigeria: Public Health Implications. Arch. Environ. Occup. Health 2020, 65, 21-26. [CrossRef]

18. Xiao, Y.; Bai, X.; Ouyang, Z.; Zheng, H.; Xing, F. The Composition, Trend and Impact of Urban Solid Waste in Beijing. Environ. Monit. Assess. 2007, 135, 21-30. [CrossRef]

19. Yongsi, H.B.N.; Herrmann, T.M.; Ntetu, A.L.; Sietchiping, R.; Bryant, C. Environmental Sanitation and Health Risks in Tropical Urban Settings: Case study of Household Refuse and Diarrhea in Yaoundé-Cameroon. Int. J. Hum. Soc. Sci. 2008, 3, $220-228$.

20. Cropper, M.L. Measuring the benefits from reduced morbidity. Am. Econ. Rev. 1981, 71, 235-240.

21. Boardi, K.O.; Kuitunen, M. Environmental and Health Impacts of Household Solid Waste Handling and Disposal Practices in the Third World Cities: The Case of Accra Metropolitan Area, Ghana. J. Environ. Health 2005, 68, 34-36.

22. Gouveia, N.; do Prado, R.R. Health Risks in Areas Close to Urban Solid Waste Landfill Sites. Rev. SaúdePública 2009, 44, 1-8. 
23. Forastiere, F.; Badaloni, C.; de Hoogh, K.; von Kraus, M.K.; Martuzzi, M.; Mitis, F.; Ranzi, A. Health impact assessment of waste management facilities in three European countries. Environ. Health 2011, 10, 53. [CrossRef] [PubMed]

24. Foday, P.S.; Xiangbin, Y.; Quangyen, T. Environmental and Health Impact of Solid Waste Disposal in Developing Cities: A Case Study of Granville Brook Dumpsite, Freetown, Sierra Leone. J. Environ. Prot. 2013, 4, 665-670.

25. Yoada, R.M.; Chirawurah, D.; Adongo, P.B. Domestic waste disposal practice and perceptions of private sector waste management in urban Accra. BMC Public Health 2014, 14, 697-707. [CrossRef]

26. Harrington, W.; Krupnick, A.J.; Spofford, W.O., Jr. The economic losses of a waterborne disease outbreak. J. Urban Econ. 1989, 25, 116-137. [CrossRef]

27. Salam, A. Environmental and Health Impact of Solid Waste Disposal at Mangwaneni Dumpsite in Manzini: Swaziland. J. Sust. Dev. Afr. 2010, 12, 23-45.

28. Karija, M.K.; Shihua, Q.I.; Lukaw, Y.S. The impact of poor municipal solid waste management practices and sanitation status on water quality and public health in cities of the least developed countries: The case of Juba, South Sudan. Int. J. Appl. Sci. Technol. 2013, 3, 87-99.

29. Karshima, S.N. Public health implications of poor municipal waste management in Nigeria. Vom J. Vet. Sci. 2016, 11, 142-148.

30. Satterthwaite, D.; Sverdlik, A.; Brown, D. Revealing and responding to multiple health risks in informal settlements in sub-Saharan African cities. J. Urban 2018, 96, 112-122. [CrossRef]

31. Bartiaux, F. Does environmental information overcome practice compartmentalization and change consumers' behaviors. J. Clean Prod. 2008, 16, 1170-1180. [CrossRef]

32. EPMC. Data Collection for Preparation of National Study on Privatization of Solid Waste Management in Eight Selected Cities of Pakistan by Engineering Planning and Management Consultants (EPMC); Pakistan Environmental Protection Agency: Lahore, Pakistan, 1996.

33. ESCAP; UN-Habitat Pakistan. Solid Waste Management in the Pakistan's Cities; Ministry of Climate Change, Government of Pakistan: Islamabad, Pakistan, 2005.

34. Mahar, A.; Malik, R.N.; Qadir, A.; Ahmed, T.; Khan, Z.; Khan, M.A. Review and analysis of current solid waste management situation in urban areas of Pakistan. In Proceedings of the Inter-National Conference on Sustainable Solid Waste Management, Chennai, India, 10-11 October 2019; pp. 34-41.

35. Mukheed, M.; Alisha, K. Plastic Pollution in Pakistan: Environmental and Health Implications. J. Pollut. Effects Control 2020, 4, 251-258.

36. Atkinson, A.; Davila, J.D.; Mattingly, M. The Challenge of Environmental Management in Urban Areas; Routledge: Oxfordshire, UK, 2019.

37. Couth, R.; Trois, C. Waste management activities and carbon emissions in Africa. Waste Manag. 2011, 31, 131-137. [CrossRef]

38. Douti, N.B.; Abanyie, S.K.; Ampofo, S. Solid waste management challenges in urban areas of Ghana: A case study of Bawku Municipality. Int. J. Geosci. 2017, 8, 494-513. [CrossRef]

39. Guerrero, L.A.; Maas, G.; Hogland, W. Solid waste management challenges for cities in developing countries. Waste Manag. 2013, 33, 220-232. [CrossRef] [PubMed]

40. World Bank. Urban Environmental Sanitation Project, Staff Appraisal Report; Africa Regional Office: Brazzaville, Republic of Congo, 2011.

41. Daud, M.K.; Nafees, M.; Ali, S.; Rizwan, M.; Bajwa, R.A.; Shakoor, M.B.; Arshad, U.M.; Chatha, S.A.S.; Deeba, F.; Murad, W. Drinking water quality status and contamination in Pakistan. BioMed Res. Int. 2017, 2017, 1-19. [CrossRef]

42. UNEP. Guidelines for National Waste Management Strategies: Moving from challenges to Opportunities; United Nations Environment Programme: Nairobi, Kenya, 2013.

43. Wazir, M.A.; Goujon, A. Assessing the 2017census of Pakistan using Demographic Analysis: A Sub-National Perspective. Available online: https:/ /www.econstor.eu/bitstream/10419/207062/1/1667013416.pdf (accessed on 2 March 2021).

44. Sheikh, I.M.; Pasha, M.K.; Williams, V.S.; Qamer Raza, S.; Khan, K.S.A. Environmental geology of Islamabad-Rawalpindi area, Northern Pakistan. In Regional Studies of Potwar Plateau Area Northern Pakistan; Warwick, P.D., Wardlaw, B.R., Eds.; USGS: Reston, VA, USA, 2007.

45. Atta, U.; Hussain, M.; Malik, R.N. Environmental impact assessment of municipal solid waste management value chain: A case study from Pakistan. Waste Manag. Res. 2020, 1-10. [CrossRef]

46. CERES Associate Gulf UAE. Improvement of Environment by Solid Waste Management in Islamabad, Pakistan. Available online: http:/ / projectpi.pk/services/solid-waste-management/ (accessed on 3 September 2017).

47. Ali, S.M.; Pervaiz, A.; Afzal, B.; Hamid, N.; Yasmin, A. Open dumping of municipal solid waste and its hazardous impacts on soil and vegetation diversity at waste dumping sites of Islamabad city. J. King Saud Univ. Sci. 2014, 26, 59-65. [CrossRef]

48. Haq, I.U.; Cheema, W.A. Adverse Effects of Poor Wastewater Management Practices on Ground Water Quality in Rawalpindi and Mitigation Strategies; Water and Sanitation Agency (WASA), Rawalpindi District Authority: Rawalpindi, Pakistan, 2001.

49. Rasheed, A.; Aneja, V.P.; Aiyyer, A.; Rafique, U. Measurements and analysis of air quality in Islamabad, Pakistan. Earth Future 2014, 2, 303-314. [CrossRef]

50. Javed, S.M.; Tufail, M.; Khalid, S. Heavy metal pollution from medical waste incineration at Islamabad and Rawalpindi, Pakistan. Micro-Chem. J. 2008, 90, 77-81.

51. Mehmood, T.; Ahmad, I. Insight into monsoon for shaping the air quality of Islamabad, Pakistan: Comparing the magnitude of health risk associated with PM 10 and PM 2.5 exposure. J. Air Waste Manag. Assoc. 2020. [CrossRef] 
52. Njoku, P.O.; Edokpayi, J.N.; Odiyo, J.O. Health and environmental risks of residents living close to a landfill: A case study of thohoyandou landfill, Limpopo province, South Africa. Int. J. Environ. Res. Public Health 2019, 16, 2125. [CrossRef]

53. Hyder, O.; Chung, M.; Cosgrove, D.; Herman, J.; Li, Z. Cadmium exposure and liver disease among US adults. J. Gastrointest. Surg. 2013, 17, 1265-1273. [CrossRef]

54. Mudga, V.; Madaan, N.; Mudgal, A.; Singh, R.B.; Mishra, A. Effect of toxic metals on human health. Open Nutraceuticals J. 2010, 3 , 94-99.

55. Ogwueleka, T.C. Survey of household waste composition and quantities in Abuja, Nigeria. Resour. Conserv. Recycl. 2013, 77, 52-60. [CrossRef]

56. Soma, T.; Li, B.; Maclaren, V. Food Waste Reduction: A Test of Three Consumer Awareness Interventions. Sustainability 2020, 12, 907. [CrossRef]

57. Vassanadumrongdee, S.; Suthirat, K. Factors influencing source separation intention and willingness to pay for improving waste management in Bangkok, Thailand. Sustain. Environ. Res. 2018, 28, 90-99. [CrossRef]

58. Moh, Y.C.; Manaf, L.A. Solid waste management transformation and future challenges of source separation and recycling practice in Malaysia. Resour. Conserv. Recycl. 2017, 116, 1-14. [CrossRef]

59. Jalan, J.; Somanathan, E. The importance of being informed: Experimental evidence on demand for environmental quality. J. Dev. Econ. 2008, 87, 14-28. [CrossRef]

60. Sessa, A.; Di Giuseppe, G.; Marinelli, P.; Angelillo, I.F. Public concerns and behaviors towards solid waste management in Italy. Eur. J. Public Health 2010, 20, 631-633. [CrossRef] [PubMed]

61. Abah, S.O.; Ohimain, E.I. Assessment of Dumpsite Rehabilitation Potential using the Integrated Risk Based Approach: A case study of Eneka, Nigeria. World Appl. Sci. J. 2010, 8, 436-442.

62. Sujauddin, M.; Huda, S.M.S.; Rafiqul, A.T.M.; Hoque, R. Household solid waste characteristics and management in Chittagong, Bangladesh. Waste Manag. 2008, 28, 1688-1695. [CrossRef]

63. Vandermoere, F. Hazard perception, risk perception, and the need for decontamination by residents exposed to soil pollution: The role of sustainability and the limits of expert knowledge. Risk Anal. 2008, 2, 387-398. [CrossRef] 